\title{
Myeloblasts 5 Percent or Less of Bone Marrow Nucleated Cells
}

National Cancer Institute

\section{Source}

National Cancer Institute. Myeloblasts 5 Percent or Less of Bone Marrow Nucleated

Cells. NCI Thesaurus. Code C154140.

A semi-quantitative microscopic finding indicating that 5 percent or less of the nucleated cells in a bone marrow sample are immature mononuclear cells of myeloid origin. 